\title{
PENGEMBANGAN PERENCANAAN PEMBELAJARAN PAUD BERBASIS BUDAYA
}

\author{
Oleh: \\ Joko Pamungkas, Nur Hayati dan Ika Budi Maryatun \\ Jurusan PAUD FIP Universitas Negeri Yogyakarta \\ joko_pamungkas uny.ac.id; nurhayati uny.ac.id; ika_budimaryatun $\overline{-}$ uny.ac.id
}

\begin{abstract}
Abstrak
Pelatihan ini bertujuan untuk meningkatkan pengetahuan guru TK tentang kurikulum 2013. Tujuan yang kedua dari pelatihan ini adalah untuk meningkatkan pemahaman dan keterampilan guru TK dalam membuat rancangan Tema, RPPM berbasis budaya.

Pelatihan ini dilaksanakan berdasarkan hasil PPM Joko Pamungkas pada tahun 2015 dimana belum semua guru mampu secara mandiri mengembangkan RPP sesuai kurikulum 2013. Tema budaya termasuk masih jarang digunakan dalam tema pembelajaran di PAUD karena dirasa sulit dikembangkan dalam kegiatan pembelajaran anak usia dini.

Metode dalam pelatihan ini berupa ceramah dan workshop. metode ceramah berisi tentang materi budaya, materi pendekatan saintifik dan materi pengembangan RPP kurikulum 2013. Khalayak sasaran adalah guru-guru TK yang ada di wilayah DIY berjumlah 37 orang. Hasil dari PPM ini antara lain guru dapat mengembangkan RPP berbasis budaya. Tema budaya yang dapat dikembangkan yaitu tema budaya, ramadhan dan rekreasi. Lebih dari 75\% peserta sudah memahami pengembangan kurikulum 2013 sesuai dengan materi dalam pelatihan ini.
\end{abstract}

Kata kunci: kurikulum, PAUD, budaya.

\begin{abstract}
The aim of the research is to improve the kindergarten teachers' knowledge about Kurikulum 2013. The second aim of the training is to develop more understanding and skill of kindergarten teachers in designing culture-based weekly lesson plans theme.

The training was carried out based on the result of community service progame done by Joko Pamungkas in 2005 in which not all of the teachers were able to autonomously develop lesson plan in Kurikulum 2013 criteria. The culture theme was also rarely used in the early chilhood education learning because of the opinion that it is hard to be developed.

Methods used in the training were in the form of lecturing and workshop. The lecturing method covered materials upon culture, scientific method, and the development of Kurikulum 2013. Objects of the community service programe were 37 kindergarten teachers in DIY.

As the result of the community service programe, teachers were able to develop culture-based lesson plan. The culture themes which can be developed were culture, Ramadhan, and recreation. More than $75 \%$ of the participants were able to understand the development of Kurikulum 2013 in line with the materials in the training.
\end{abstract}

Keywords: curriculum, early childhood education, culture

PENDAHULUAN

Kurikulum yang paling banyak dipahami oleh guru TK dalam kurun waktu 10 tahun ini adalah kurikulum 2004. Menurut beberapa guru TK merasa mudah menerapkan kurikulum tersebut karena cukup lama menekuni dan tema serta indikator sudah ditentukan oleh perancang kurikulum dari Dinas Pendidikan. Dengan demikian guru tinggal menerapkan di kurikulum sekolah tanpa banyak kesulitan. Namun pada perjalanan selanjutnya 
dimunculkan kurikulum 2010 hasil dari terbitnya Permendiknas No. 58 tahun 2009 tentang standar nasional pendidikan anak usia dini. Beberapa guru mulai belajar memahami kurikulum 2010 yang dirasa lebih banyak menuntut kreativitas guru dalam membuat indikator. Pada akhirnya banyak guru yang memadukan indikator di kurikulum 2004 yang tidak semuanya sesuai dengan kurikulum 2010. Beberapa masukan mulai bermunculan hingga pada tahun 2014 ditetapkan Permendikbud no.137 tahun 2014 tentang standar nasional pendidikan anak usia dini.

Jika dikaji dari segi waktu, perubahan dan perbaikan kurikulum tersebut bisa dianggap wajar seiring dengan perubahan yang terjadi. Tetapi ketidakwajaran muncul tatkala perubahan dan perbaikan kurikulum tersebut tidak berdampak pada peningkatan kualitas dan relevansi pendidikan dengan tuntutan dan kebutuhan masyarakat, bahkan terjadi sebaliknya dimana hasil pendidikan menurun kualitasnya.

Berbagai upaya telah banyak dilakukan, namun hasil yang diperoleh sampai saat ini belumlah menggembirakan. Salah satu upaya yang saat ini sedang dilakukan adalah melakukan sosialisasi kurikulum. Pada tahun 2014 mulai diberlakukan kurikulum 2013 di tingkat Pendidikan Anak Usia Dini, namun sampai tahun 2015 belum semua lembaga PAUD melaksanakan kurikulum 2013 karena berbagai kendala salah satunya belum pernah mendapatkan sosialisasi. Kendala tersebut banyak dihadapi oleh lembaga PAUD yang terletak di daerah terpencil dan sering kesulitan mengakses informasi dari Dinas Pendidikan Kebudayaan maupun dari Lembaga Pendidikan Tinggi seperti UNY.

Sesuai dengan Peraturan Menteri Pendidikan dan Kebudayaan No. 137 Tahun 2014 tentang Standar Nasional Pendidikan Anak Usia Dini bahwa Kompetensi Guru PAUD mencakup kompetensi pedagogik, kepribadian, sosial, dan profesional. Salah satu kompetensi pedagogik yang harus dimiliki oleh pendidik PAUD adalah merancang kegiatan pengembangan anak usia dini berdasarkan kurikulum. Guru akan mampu merancang kurikulum apabila memahami bagaimana mengembangkan tema dan merancang kegiatan bermain dalam bentuk program tahunan, semester, mingguan dan harian sesuai dengan kebutuhan anak usia dini.

Salah satu tema yang dapat dikembangkan pendidik untuk menstimulasi perkembangan anak adalah tema berbasis budaya. Berdasarkan hasil pengabdian pada masyarakat yang dilakukan Joko Pamungkas tahun 2015 tentang Lagu Dolanan Tradisional pada Kader PAUD, masih banyak guru TK belum mampu mengemas kegiatan pembelajaran berbasis budaya. Pemaknaan filosofi permainan kurang dipahami anak meskipun anak didik senang melakukan permainan tradisonal.

Kondisi yang terjadi di lapangan masih banyak pendidik PAUD khususnya guru TK yang belum memahami cara mengembangkan kurikulum yang sesuai dengan kebutuhan anak karena pada kurikulum sebelumnya guru mengembangkan kurikulum di sekolah yang sudah dibuat oleh tim IGTK atau Himpaudi setempat. Kegiatan pembelajaran berbasis budaya juga belum banyak dikemas secara menarik sehingga anak didik belum sepenuhnya memaknai secara mendalam tentang pesan tersirat dibalik kegiatan. Berdasarkan realita tersebut perlu diadakan workshop pengembangan kurikulum PAUD 2013 secara berkala agar semua pendidik PAUD dapat memahami perangkat kurikulum yang isinya sedikit berbeda dengan kurikulum-kurikulum sebelumnya khususnya pengembangan kurikulum berbasis budaya. Kegiatan workshop yang berkala tersebut juga dapat meningkatkan kualitas kompetensi pedagogik guru yang harapannya dapat meningkatkan kompetensi lainnya serta berimbas pada 
peningkatan kemampuan anak usia dini secara merata.

Tujuan pertama kegiatan PPM ini antara lain untuk meningkatkan pengetahuan guru TK tentang kurikulum 2013. Tujuan yang kedua adalah untuk meningkatkan pemahaman dan keterampilan guru TK dalam membuat rancangan Tema, RPPM berbasis budaya.

Kegiatan PPM ini diharapkan bermanfaat untuk guru TK dalam meningkatkan pengetahuan dan pemahaman mengenai kurikulum 2013 yang mengharuskan guru untuk merancang sendiri tema pembelajaran sesuai dengan kebutuhan anak usia dini, membuat Tema dan RPPM. Dengan adanya workshop kurikulum 2013 diharapkan guru TK mempunyai pengalaman langsung menyusun perangkat pembelajaran yang tematik dan berbasis budaya di sekolahnya.

\section{KURIKULUM PAUD}

Kurikulum PAUD sesuai dengan Pedoman Perencanaan Pembelajaran Anak Usia Dini (Direktorat Pembinaan PAUD,2014) adalah seperangkat rencana dan pengaturan mengenai tujuan, isi, dan bahan pengembangan serta cara yang digunakan sebagai pedoman penyelenggaraan kegiatan pengembangan untuk mencapai tujuan pendidikan tertentu. Kurikulum PAUD terdiri dari perencanaan program semester berupa pengembangan tema, RPPM dan RPPH.

Perencanaan program semester berisi daftar tema satu semester termasuk alokasi waktu setiap tema dengan menyesuaikan hari efektif kalender pendidikan yang bersifat fleksibel. Tema berfungsi sebagai wadah yang berisi bahan kegiatan untuk mengembangkan potensi anak dan menyatukan seluruh kompetensi dalam satu kesatuan yang lebih berarti, memperkaya wawasan dan perbendaharaan kata anak sehingga pembelajaran menjadi lebih bermakna. Penentuan tema dapat dikembangkan oleh guru TK mengacu pada contoh tema yang ada dalam Panduan.

Perencanaan program mingguan merupakan rencana kegiatan yang disusun untuk pembelajaran selama satu minggu. Perencanaan kegiatan mingguan dapat berbentuk jaringan tema (web). Jaringan tema berisi projek- projek yang akan dikembangkan menjadi kegiatan-kegiatan pembelajaran. Pada akhir satu atau beberapa tema dapat dilaksanakan kegiatan puncak tema yang -menunjukkan prestasi peserta didik. -Puncak tema dapat berupa kegiatan antara lain membuat kue/makanan, makan bersama, pameran hasil karya, pertunjukan, panen tanaman, dan kunjungan.

Rencana pelaksanaan pembelajaran harian (RPPH) adalah perencanaan program harian yang akan dilaksanakan oleh pendidik/pengasuh pada setiap hari atau sesuai dengan program lembaga. Komponen RPPH, antara lain: tema/sub tema/sub-sub tema, alokasi waktu, hari/tanggal, kegiatan pembukaan, kegiatan inti, dan kegiatan penutup. RPPH adalah perencanaan program harian yang akan dilaksanakan oleh pendidik/pengasuh pada setiap hari atau sesuai dengan program lembaga. Komponen RPPH, antara lain: tema/sub tema/sub-sub tema, alokasi waktu, hari/tanggal, kegiatan pembukaan, kegiatan inti, dan kegiatan penutup.

\section{BUDAYA}

Kebudayaan dirumuskan sebagai keseluruhan gagasan dan karya manusia yang harus dibiasakan dengan belajar, beserta keseluruhan dari hasil budi dan karyanya itu (Koentjaraningrat, dalam Ika Budi Maryatun 2013:3). Pendapat lain dikemukakan oleh Kuper dalam Ika Budi maryatun 2013:3 bahwa budaya merupakan suatu cara hidup yang berkembang dan dimiliki bersama oleh sebuah kelompok orang dan diwariskan dari generasi. Dengan demikian dapat disimpulkan bahwa budaya merupakan cara hidup sebagai hasil dari gagasan 
manusia dalam sebuah kelompok masyarakat dan diwariskan turun temurun.

\section{METODE KEGIATAN PPM}

\section{Kerangka Pemecahan Masalah}

Selama ini pendidik PAUD khususnya guru TK mempunyai peran yang luar biasa untuk menstimulasi dan mengembangkan potensi anak usia dini. Guru-guru TK selama ini sudah mampu merancang kegiatan pembelajaran berdasarkan kurikulum 2004 dan kurikulum 2010. Namun tidak semua guru-guru TK mampu menyusun perencanaan pembelajaran berbasis kurikulum 2013 serta kegiatan pembelajarn berbasis budaya. Hal tersebut dapat dimaklumi karena sosialisasi kurikulum 2013 belum dilakukan secara merata dan tingkat pemahaman setiap guru juga beragam. Sehingga masih banyak guru TK yang masih kesulitan merancang kegiatan pembelajaran berdasarkan kurikulum 2013 khususnya berbasis budaya.

Berdasarkan kondisi tersebut, maka pemecahan masalah yang diajukan dalam PPM ini adalah dengan menyelenggarakan kegiatan dan workshop kurikulum 2013 bagi guru-guru TK di wilayah DIY agar mereka mengetahui bagaimana cara menyusun perencanaan pembelajaran mulai dari mengembangkan tema dan membuat RPPM yang tematik dan berbasis budaya sesuai dengan kebutuhan anak didiknya.

\section{Khalayak sasaran}

Khalayak sasaran yang dituju dalam pelatihan ini adalah 37 orang guru TK yang ada di wilayah kerja DIY khususnya yang belum pernah mengikuti pelatihan pembuatan kurikulum PAUD 2013.

\section{Keterkaitan}

1. Jurusan Pendidikan Anak Usia Dini (PAUD) dan Fakultas Ilmu Pendidikan Universitas Negeri Yogyakarta.
Beberapa dosen terkait akan dilibatkan sebagai narasumber, trainer, atau instruktur dalam penyuluhan ini.

2. TK ABA Demakan Gadingsari Sanden Bantul, TK PKK 106 Merten Sanden Bantul, TK ABA Pendekan Tirtohayu Kulonprogo, TK ABA Dekso Kulonprogo, TK KKLKMD Plebengan Palbapang bantul, TK Negeri Pembina Brosot Kulonprogo, TK ABA 1 Brosot Kulonprogo, TK PKK Marsudisiwi Gunung Kelir Pleret bantul, TK Kemala Bhayangkari 4, TK Negeri Pembina Bantul, TK Kartika 1V-38, Tk Angkasa, TK Kemala Bhayangkari 05 dan TK Kemala Bhayangkari 02 Bachiro Yogyakarta

3. Mahasiswa Program Studi PAUD FIP UNY dilibatkan dalam bentuk partisipasi dalam membantu pelaksanaan kegiatan.

\section{Metode Kegiatan}

Kegiatan dilaksanakan dalam bentuk ceramah materi budaya dan kurikulum 2013 dan workshop pengembangan RPP (webbing tema, Prosem dan RPPH) kurikulum 2013 berbasis budaya.

\section{Evaluasi}

Evaluasi kerja yang dilaksanakan meliputi evaluasi pemahaman peserta terhadap materi. Evaluasi ini dilaksanakan dengan menggunakan FGD. Evaluasi bagian ini meliputi diskusi secara mendalam dengan peserta secara berkelompok (Focus Group Discusion). Evaluasi tahap kedua adalah evaluasi terhadap hasil workshop berupa masukan dan perbaikan pengembangan tema dan RPPM yang telah dikerjakan oleh peserta. Evaluasi ini dilakukan dengan mengacu pada kisi-kisi tentang pedoman pembuatan pengembangan tema dan RPPM kegiatan pembelajaran berbasis budaya. 


\section{HASIL PPM DAN PEMBAHASAN}

\section{Hasil Pelaksanaan Kegiatan}

Program Workshop Pengembangan Kurikulum PAUD 2013 Berbasis Budaya ini dilaksanakan dengan melibatkan guru TK di beberapa Kabupaten dalam lingkup DIY telah diikuti oleh 37 orang. Kegiatan ini dilakukan dengan ceramah dan workshop. Kegiatan workshop dilaksanakan pada hari Rabu 1 Juni 2016. Kegiatan ini terbagi ke dalam 4 (empat) sesi. Adapun deskripsi pelaksanaan kegiatan pelatihan sebagai berikut:

\section{Sesi Pertama}

Pelaksanaan sesi pertama ini dilaksanakan pada tanggal 1 Juni 2016 diisi dengan ceramah yang berjudul Kebudayaan. Ceramah ini disampaikan oleh Bapak Joko Pamungkas, M.Pd yang memang memiliki keahlian di bidang terkait. Perlunya diberikan wawasan mengenai Kebudayaan agar guru benarbenar memahami sejarah budaya khususnya di wilayah DIY dan dapat menyampaikan informasi tentang budaya pada peserta didik. Dengan mengetahui konsep budaya yang tepat, guru dapat mengembangkan tema lebih kreatif, tidak hanya tema yang penah ada di kurikulum sebelumnya. Karena pada kurikulum 2013 guru dituntut untuk bisa mengembangkan tema dan materi pembelajaran yang sesuai dengan kebutuhan peserta didik.

\section{Sesi Kedua}

Pelaksanaan sesi kedua ini diisi
dengan ceramah yang berjudul
"Pendekatan Saintifik dalam Kurikulum 2013". Ceramah ini disampaikan oleh Nur Hayati, M.Pd yang memang memiliki keahlian di bidang terkait. Perlunya diberikan pengetahuan tentang pendekatan saintifik dalam pembelajaran anak usia dini, agar guru lebih memahami proses saintifik yang benar dan sebagai dasar dalam mengembangkan materi pembelajaran. Selanjutnya jika guru memahami yang dimaksud pendekatan saintifik dalam kurikulum 2013, maka guru dapat menerapkan tahapan proses saintifik dalam RPPM dan RPPH. Proses saintifik dalam pembelajaran harus ditulis di RPPH sebagai suatu tahapan darai kegiatan awal sampai akhir pembelajaran atau dapat juga sebagai proses yang muncul menyatu saat apersespsi. Dengan demikian peserta didik dapat lebih memahami semua kegiatan yang dilakukan dan mengetahui bagaimana manfaat materi pembelajaran yang telah mereka dapatkan.

\section{Sesi Ketiga}

Pelaksanaan sesi ketiga dilaksanakan pada hari Rabu 1 Juni 2016. Kegiatan ini diisi dengan materi berjudul "Pengembangan Rencana Pembelajaran Kurikulum 2013". Ceramah ini disampaikan oleh Ibu Ika Budi Maryatun, M.Pd yang memang memiliki keahlian di bidang terkait. Perlunya diberikan langkah-langkah mengembangkan RPP sesuai kurikulum 2013 agar semua guru di DIY memiliki persepsi yang sama mengenai perangkat pembelajaran berdasarkan kurikulum 2013. Pengetahuan ini dapat dijadikan landasan bagi guru yang masih belum sepenuhnya memahami cara membreakdown Kompetensi Inti dan Kompetensi Dasar, cara mengembangkan Tema dan materi pembelajaran sampai pada RPPH. Dengan pengetahuan ini diharapkan guru-guru TK lebih memahami bagaimana mengembangkan RPP berdasarkan kurikulum 2013 secara mandiri serta sesuai dengan kebutuhan peserta didik.

\section{Sesi Keempat}

Kegiatan sesi keempat ini diisi dengan diskusi kelompok dan workshop pengembangan tema berbasis budaya. Setelah workshop kegiatan pengembangan tema, dilanjutkan dengan pembuatan RPPM dan RPPH. Kegiatan ini dipandu oleh Ibu Nur Hayati, M.Pd, Ika Budi Maryatun, M.Pd dan Bapak Joko Pamungkas, M.Pd. Peserta sosialisasi dibagi menjadi 7 kelompok untuk 
mengembangkan tema dan merancang pembelajaran berbasis budaya. Kelompok tersebut antara lain kelompok TK Bantul, TK Kulonprogo, TK Kartika 1V-38, TK Angkasa, TK Kemala Bhayangkari 4, TK Kemala Bhayangkari 05, TK Kemala Bhayangkari 02.

Antusiasme peserta dalam kegiatan ini cukup baik. Beberapa guru yang hadir sebagai peserta workshop kurikulum PAUD 2013 sebagian ada yang masih kesulitan membagi KI dan KD dalam program semester serta membuat materi. Dengan demikian TIM PPM menyepakati kegiatan workshop hanya membuat webbing tema, program semester dan RPPH.

Keterbatasan tersebut cukup wajar, karena banyak guru TK yang belum paham betul penerapan kurikulum 2013. Sehingga ketika akan melaksanakan kurikulum 2013 yang komponennya terdiri dari pengembangan tema, pemetaan $\mathrm{KI}$ dan KD dalam program semester, pengembangan RPPM, Penyusunan Tujuan Pembelajaran dan Indikator Pencapaian Pekembangan, pengembangan RPPH.

Setelah melalui beberapa diskusi, mulai ditemukan beberapa cara efektif untuk mengembangkan tema, program semester dan RPPH. Dari kegiatan ini diharapkan kesulitan-kesuliatan yang dihadapi peserta workshop pengembangan RPP kurikulum 2013 ini dapat terselesaikan berdasarkan penjelasan dari narasumber.

\section{PEMBAHASAN}

Kemampuan guru TK dalam merancang kegiatan pengembangan pembelajaran anak usia dini berdasarkan kurikulum yang berlaku merupakan suatu hal yang mutlak dikuasai. Guru seharusnya mampu merancang kurikulum apabila memahami bagaimana mengembangkan tema dan merancang kegiatan bermain dalam bentuk program tahunan, semester, mingguan dan harian sesuai dengan kebutuhan anak usia dini.
Berdasarkan Pedoman Perencanaan Pembelajaran Anak Usia Dini (Direktorat Pembinaan PAUD, 2014), kurikulum PAUD adalah seperangkat rencana dan pengaturan mengenai tujuan, isi, dan bahan pengembangan serta cara yang digunakan sebagai pedoman penyelenggaraan kegiatan pengembangan untuk mencapai tujuan pendidikan tertentu. Kurikulum PAUD terdiri dari perencanaan program semester berupa pengembangan tema, RPPM dan RPPH. Kurikulum yang dikembangkan oleh guru beberapa TK di wilayah DIY sudah sesuai dengan pedoman yaitu mengembangkan tema dengan proses berpikir saintifik, namun belum semua guru mampu mengembangkan tema berbasis budaya. Hal tersebut dapat dipahami karena selama ini masih banyak guru yang belum pernah secara mandiri mengembangkan RPP sesuai dengan kreatifitasnya.

Fakta lain yang ditemukan Tim PPM bahwa hampir sebagian guru TK tidak membuat tujuan pembelajaran dan indikator pencapaian perkembangan sebagai pedoman pengembangan RPPH dan Penilaian. Hal tersebut dapat dimaklumi karena guru TK di DIY mendapatkan pelatihan pengembangan perangkat pembelajaran dari tutor yang berbeda-beda. Sehingga di beberapa TK bentuk dan format RPPnya beragam.

Pendapat lain dikemukakan oleh Kuper dalam Ika Budi Maryatun 2013:3 bahwa budaya merupakan suatu cara hidup yang berkembang dan dimiliki bersama oleh sebuah kelompok orang dan diwariskan dari generasi. Dengan adanya workshop ini, guru diharapkan dapat lebih banyak mengenalkan budaya disekitar anak yang dituangkan dalam bentuk kegiatan pembelajaran. Berbagai tema berbasis budaya dapat dikembangkan dalam bentuk tema budaya, tema ramadhan, tema rekreasi dan sebagainya. Implementasi pembelajaran budaya akan lebih tampak pada rancangan RPPH. Dalam rancangan $\mathrm{RPPH}$, tampak beberapa kegiatan bermain yang bernuansa budaya 
dan sesuai dengan proses saintifik. Dengan demikian pengembangan rancangan perangkat pembelajaran kurikulum 2013 akan lebih memperkaya ilmu dan informasi anak usia dini dalam memahami budaya. Berikut ini gambar pengembangan tema budaya:

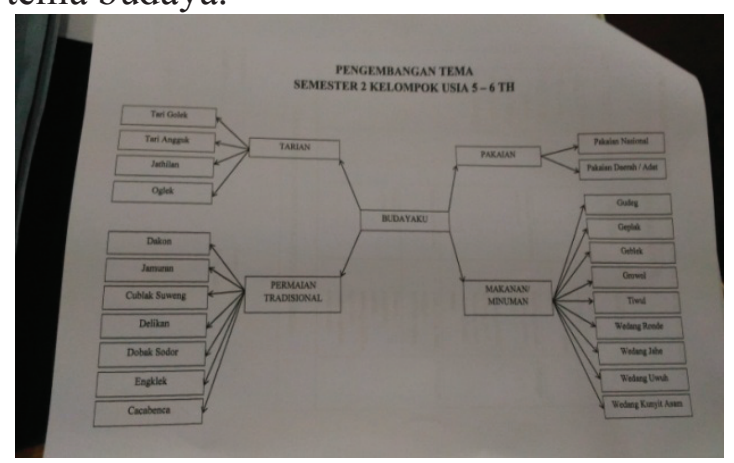

Gambar 01.

Webbing Tema Budaya

Webbing tema budaya pada gambar 01 tersebut dikembangkan oleh guru TK ABA 1Brosot Galur Kulonprogo. Sub tema yang dikembangkan oleh guru TK ABA 1 Brosot antara lain sub tema tarian, permainan tradisional, makanan dan minuman, serta pakaian. Sub-sub tema yang dikembangkan dalam RPPH adalah sub-sub tema pakaian adat jawa

Guru dapat menginformasikan tentang budaya Jawa saat apersepsi pembelajaran pakaian adat jawa. Guru dapat menunjukkan gambar gambar pakaian adat Jawa atau contoh asli pakaian adat Jawa, lalu memberi kesempatan anak didik untuk mengamati dan bertanya tentang pakaian adat Jawa. Anak dapat mengumpulkan informasi tentang pakaian adat Jawa melalui mengamati gambar atau mencoba pakaian adat Jawa. Kemudian anak dapat menalar bagaimana bentuk dan bahan pakaian adat Jawa selanjutnya dapat mengkomunikasikan bagaimana ciri-ciri pakaian adat Jawa. Proses yang dilalui anak didik saat kegiatan apersepsi tersebut merupakan proses saintifik.

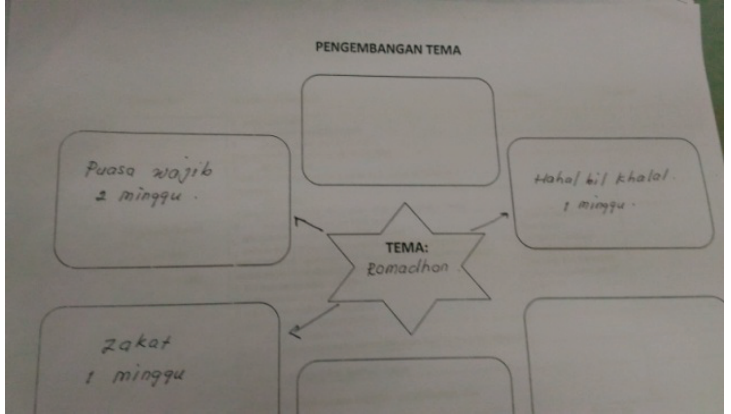

Gambar 02.

Webbing Tema ramadhan

Webbing tema Ramadhan pada gambar 02 tersebut dikembangkan oleh TK Kemala Bhayangkari 05 Sleman. Sub tema yang dikembangkan antara lain sub tema puasa wajib, zakat, halal bi halal. Sub-sub tema yang dikembangkan dalam RPPH adalah sub-sub tema makanan khas Ramadhan.

Guru menginformasikan tentang makanan khas Ramadhan saat apersepsi pembelajaran dengan tema Ramadhan. Guru dapat menunjukkan gambar gambar atau video makanan khas yang dihidangkan saat berbuka puasa di bulan Ramadhan, lalu memberi kesempatan anak didik untuk mengamati dan bertanya tentang menu makanan saat berbuka puasa. Anak dapat mengumpulkan informasi tentang makanan khas yang dihidangkan di bulan ramadhan melalui makan makanan khas ramadhan yang dibawakan guru atau orang tua. Kemudian anak dapat menalar bagaimana bentuk dan rasa makanan khas yang ada di bulan ramadhan selanjutnya dapat mengkomunikasikan apa saja jenis makanan khas yang ada di bulan Ramadhan. Proses yang dilalui anak didik saat kegiatan apersepsi tersebut merupakan proses saintifik. 


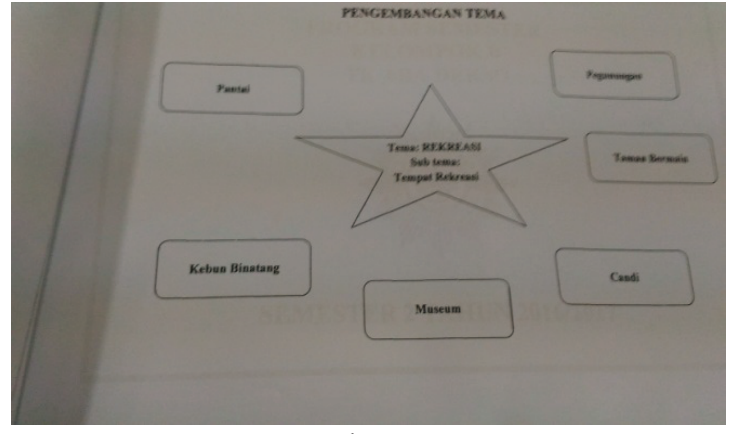

Gambar 03.

Webbing Tema Rekreasi

Webbing tema rekreasi pada gambar 03 tersebut dikembangkan oleh guru TK ABA Dekso Kulonprogo. Sub tema yang dikembangkan oleh guru TK ABA Dekso Kulonprogo antara lain sub tema pantai, kebun binatang, museum, candi, taman bermain, pegunungan. Subsub tema yang dikembangkan dalam RPPH adalah sub sub tema tempat rekreasi.

Guru menginformasikan tentang
tempat rekreasi saat apersepsi pembelajaran dengan tema Rekreasi. Guru dapat menunjukkan gambar gambar atau video tempat rekreasi di sekitar Yogyakarta, lalu memberi kesempatan anak didik untuk mengamati dan bertanya tentang lokasi tempat rekreasi di Yogyakarta. Anak dapat mengumpulkan informasi tentang tempat rekreasi melalui mengamati gambar atau video atau dapat juga wawancara pada teman maupun Guru tentang tempat rekreasi yang ada di Yogyakarta. Kemudian anak dapat menalar macam macam tempat rekreasi yang ada di Yogyakarta dan selanjutnya dapat mengkomunikasikan jumlah maupun ciri khas tempat rekreasi yang ada di Yogyakarta.

Proses yang dilalui anak didik saat kegiatan apersepsi tersebut merupakan proses saintifik.

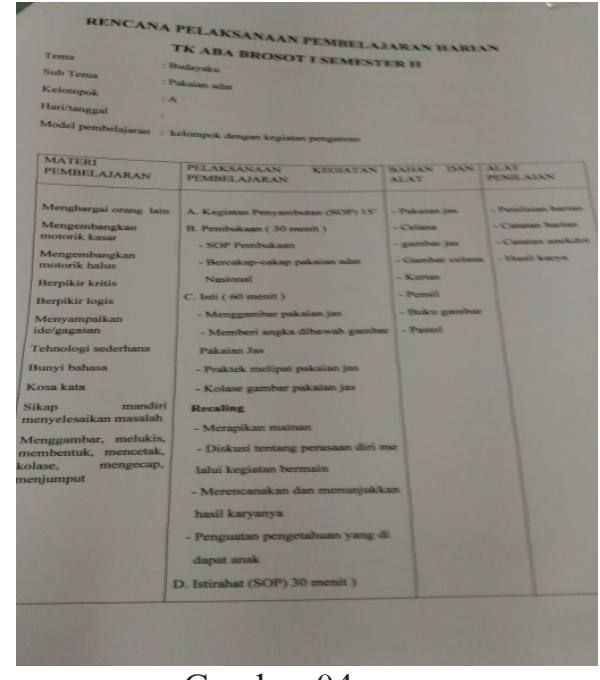

Gambar 04.

RKH TK ABA 1 Brosot Kulonprogo

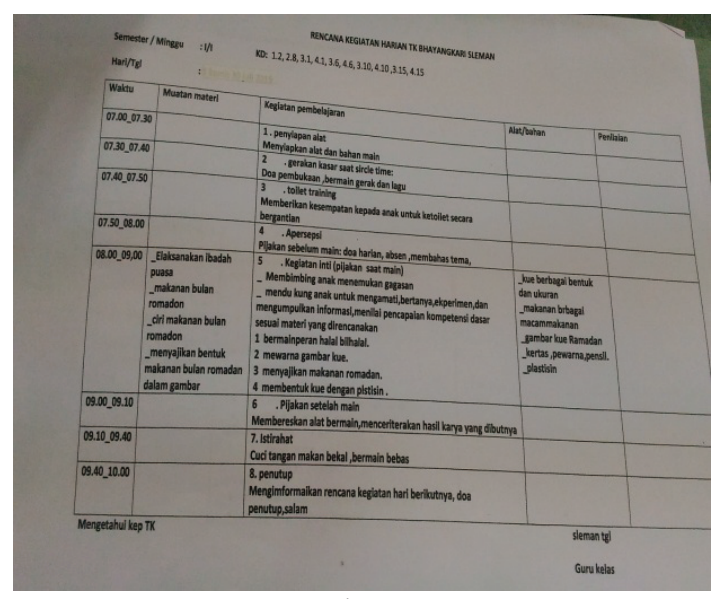

Gambar 05.

RKH TK Kemala Bhayangkari 05 Sleman

Berdasarkan gambar 04 dan gambar 05 di atas dapat kita lihat bahwa penjelasan tentang budaya akan lebih tampak dan detail dijelaskan dalam kegiatan harian. Penjelasan tentang budaya dapat disampaikan mulai awal kegiatan pembelajaran sampai penutupan. Dengan demikian wawasan yang berkaitan dengan makanan khas ramadhan dan pakaian adat dapat diterima anak didik dengan jelas.

Proses saintifik juga lebih tampak dalam RKH tersebut. Guru mengarahkan anak untuk aktif mengamati, bertanya, mengumpulkan informasi, menalar dan mengkomunikasikan kegiatan yang dilakukan selama satu hari.

Beberapa TK lainnya yang ikut menjadi peserta pelatihan membuat pengembangan tema belum sesuai dengan 
tema payung Budaya. TK tersebut antara lain TK PKK Marsudi siwi dengan tema kebutuhanku, TK ABA Demakan Sanden dengan tema diri sendiri. Meskipun demikian guru sebagai perwakilan peserta pelatihan lebih mengerti bagaimana mengembangkan tema, RPPM dan RPPH sesuai dengan Kurikulum 2013.

\section{Faktor Pendukung Kegiatan}

Kegiatan Workshop Kurikulum PAUD 2013 Berbasis Budaya terlaksana berkat kerja sama antar anggota TIM PPM serta adanya kerja sama dengan TK Mitra PPL dan TK Mitra Kegiatan Festival Wayang Bocah PAUD di wilayah DIY. Tempat serta fasilitas kegiatan didukung sepenuhnya oleh TIM PPM bekerjasama dengan mahasiswa PAUD FIP UNY. Dengan demikian acara dapat berjalan lancar sesuai dengan harapan.

\section{Faktor Penghambat Kegiatan}

Beberapa peserta yang belum berpengalaman mengembangkan RPP sesuai kurikulum 2013, cukup kesulitan mengembangkan Tema kegiatan pembelajaran berbasis Budaya. Sehingga saat kegiatan workshop masih ada yang mengembangkan Tema selain tema Budaya. Namun demikian, RPP peserta dapat terselesaikan dengan beberapa masukan dan revisi dari Tim PPM.

\section{SIMPULAN}

Pelatihan ini dapat meningkatkan pemahaman guru TK di beberapa wilayah DIY mengenai pembuatan rancangan RPP yang dibuktikan dengan kemampuan guru untuk menyusun tema, RPPM dan RPPH. Guru TK di beberapa wilayah DIY mampu menyusun kegiatan pembelajaran berbasis budaya. Implementasi hasil pelatihan belum dapat diamati secara langsung karena keterbatasan TK yang belum semuanya melaksanakan pembelajaran berdasarkan kurikulum 2013

\section{SARAN}

Perlu adanya pelatihan pembuatan RPP berdasarkan kurikulum 2013 secara berkelanjutan dari pihak UNY bekerjasama dengan Dinas Pendidikan dan Kebudayaan DIY. Perlunya kerjasama yang berkolaborasi tersebut agar semua guru TK di DIY memiliki persepsi yang sama mengenai rancangan kegiatan pembelajaran sesuai kurikulum 2013

\section{DAFTAR PUSTAKA}

Ika Budi maryatun. (2013). Panduan Pengembangan Kegiatan Pembelajaran Berbasis Budaya. Yogyakarta: Laporan Penelitian FIP UNY

Tim Direktorat Pembinaan PAUD. (2014). Pedoman Penyusunan Perencanaan Pembelajaran PAUD. Jakarta: Direktorat Jenderal Pendidikan Anak Usia Dini, Nonformal, Dan Informal Kementerian Pendidikan Dan Kebudayaan RI 